Digital Press Social Sciences and Humanities

Gotong Royong in Indonesian History

Nicholas Simarmata, Kwartarini Wahyu Yuniarti, Bagus Riyono and Bhina Patria

Proceeding of The 10th International Conference of Indigenous and Cultural Psychology 2019

Kwartarini Wahyu Yuniarti, Donald H. Saklofske, Rosnah Ismail, Saadi Lahlou (eds) 


\title{
Gotong Royong in Indonesian History
}

\author{
Nicholas Simarmata ${ }^{1, *}$, Kwartarini Wahyu Yuniarti ${ }^{2}$, Bagus Riyono $^{2}$, and Bhina Patria ${ }^{2}$ \\ 1 Psychology Study Program, Medical Faculty, Udayana University, Bali, Indonesia \\ 2 Psychology Faculty, Gadjah Mada University, Yogyakarta, Indonesia \\ *e-mail: nicholas@unud.ac.id
}

\begin{abstract}
Gotong Royong, as an Indonesian national identity, is not a new concept because it is a long-standing Indonesian cultural value. As an Indonesian ancestor legacy, in the form of immaterial asset, Gotong Royong has been indicated to have been deeply rooted in the Indonesian society's life. Therefore, there is a need to study and explore the meaning and history of Gotong Royong. This study employs library research, which allows the use of references in the form of articles, books, and journals as its primary data of analysis. The result of this study is that Gotong Royong has existed since Before Christ (B.C.) to the present. The conclusion of this study is the expectation that Gotong Royong is continually maintained as the way of life for Indonesians because Gotong Royong is evident in Pancasila, Bhineka Tunggal Ika, and in living a democratic life.
\end{abstract}

\section{Keywords}

culture value, gotong royong, history, national identity

\section{Introduction}

Indonesia is a country that consists of many islands with many ethnicities, commonly known for its diverse cultural values. One of those is the Gotong Royong cultural value, which becomes one of the identities of Indonesia. It is a value deeply rooted in the country's ideology, Pancasila, because it becomes the basis for Indonesian people's social solidarity.

The word Gotong Royong comes from the Javanese (Pranowo, 2010) to literally mean work (gotong), and together (royong) (Kamsori, Santosa, \& Moe'is, 2007; KBBI, 2002; Panjaitan, 2013; Pranadji, 2009; Rochmadi, 2012; Simarmata et al., 2017; Suwondo, 1982). The word gotong is usually equated with the word pikul (lift). For example, in the past, Javanese people will collaboratively help build their neighbor's house (e.g., lifting woods and stones together) (Kamsori et al., 2007; KBBI, 2002; Panjaitan, 2013; Pranadji, 2009; Pranowo, 2010; Rochmadi, 2012; Simarmata et al., 2017; Suwondo, 1982). In this way, the building up of a Javanese Indonesian's house or whatever the community is doing together can be quickly done. This is why the word royong (KBBI, 2002; Panjaitan, 2013; Pranadji, 2009; Rochmadi, 2012; Simarmata et al., 2017; Suwondo, 1982) always follow after the word gotong to suggest that the Javanese enjoy helping each other by lifting things together so that whatever needs to be done can be done quickly (Bintarto, 1980; Khasanah, 2013; Koentjaraningrat, 1961; Panjaitan, 2013; Prawiroatmodjo, 1981; Rochmadi, 2012; Simarmata et al., 2017; Suwondo, 1982; Tashadi, Gatot, \& Sukirman, 1982).

Gotong Royong is not only applicable for the Javanese, but it is an immaterial legacy of the ancestors of the people of Indonesia. Although Gotong Royong originates from the Javanese culture, it has developed in Indonesian society for a long time, being deeply rooted in the lives of the many cultures of Indonesia. Consequently, Gotong Royong becomes identical with one of Indonesia's cultural values. Nowadays, the use of modern technology due to industrializations has produced an excess of the relationship among humans, which includes the Indonesians. The possibility of doing things on their own with modern technology influenced Indonesian people to rely on their own strength and has in turn, decrease the old tradition of seeking help from their neighbors or friends to finish one's activity in togetherness.

Although on the one hand, Indonesian people are considered ready to go with the flow of being independent beings in the modern world, on the other hand, it becomes one of the factors of the almost diminishing Gotong Royong. An individualistic trait that does not care about the welfare of others is becoming an extreme pole of the modern Indonesian (Ancok, 2004). As a consequence, some Indonesian 
society are beginning to turn from group hegemony, and instead turn to defeating each other by relying on modern technology to do their selfish behavior (Fajarini, 2014; Lembaga Ketahanan Nasional Republik Indonesia, 2015a; Raharjo, 2010; Setiawan, 2013). It becomes a great concern to find that some Indonesians has not only turned to being selfish individuals, but also becoming materialistic (Dewantara, 2017a). The desire to fulfill monetarial demands is assumed to have ruled out the moral or ethical values originally contained in the spirit of Gotong Royong (Effendi, 2013; Hardiman, 1980). In other words, materialism and modernism seem to be one cause for the almost collapse of Gotong Royong (Mustaqim, 2013).

This article wants to show a more detailed viewpoint of how Gotong Royong as a cultural value and spirit of togetherness has come about in Indonesia. Not only will the article trace the cultural value back to the ancient Javanese culture, but also to how it has developed in other cultures of Indonesia, such as that from Nias, Toraja and Sumba.

Being a strong cultural value, this article discusses on how Gotong Royong has also helped shape the Indonesian history and how it has been applied in the daily lives of people. Using the historical information on Gotong Royong, this article can help emphasize the first President of Indonesia, namely Soekarno, who initiated the importance of Gotong Royong as a platform to strongly unite the multicultural country of Indonesia.

\section{Literature Review}

Gotong Royong has been introduced to be the basis of the Indonesian way of life. With Gotong Royong, the Indonesian people is said to enjoy the life living in harmony among the multi cultures and religions found in Indonesia. What is actually the definition of Gotong Royong? How do literatures or people perceive Gotong Royong? Is it a spirit, principle or cultural value? The following paragraphs are dedicated to the discussion.

\subsection{Gotong Royong is A Spirit}

Gotong Royong is a spirit of having cohesiveness in doing a national team work in Indonesia (Marcillia \& Ohno, 2012; Pasya, 1987). It is a spirit, which must continue to be instilled fromany start of family life, society and nationhood (Fajarini, 2014; Mustaqim, 2013). By having the spirit of Gotong Royong, Indonesian citizens can together solve any kinds of problems (Gunardo, 2013). All parties involved in Gotong Royong are usually encouraged to have the same passion, namely the spirit of equality (Rahayu, Ludigdo, Irianto, \& Nurkholis, 2015).

In Gotong Royong, people are encouraged to have the spirit of helping each other, so that everyone can optimize their own ability to develop themselves and their social life. With this kind of perspective, the working spirit of Gotong Royong becomes the main ingredient for social solidarity, humanity and unity (Pranowo, 2010).

\subsection{Gotong Royong is A Cultural Value}

Culture is an inheritance that cannot be separated from every nation. Culture forms a characteristic that distinguishes a nation from another. Gotong Royong is one of the Indonesian national cultures which contains many positive values (Tjahjandari, Setyani, Pembayun, \& Kurnia, 2017). Therefore, in addition to being the spirit of Indonesian citizens for totherness, Gotong Royong is also a cultural value. As a cultural value, it has been attached deeply to the Indonesian people and has variations in its designation as follows.

Some call Gotong Royong as the value of Indonesian culture (Bintarto, 1980; Djamari, 2016; Firmanzah, 2017; Hofstede, 1994; Julaikha \& Bahri, 2014; Latif, 2015; Pranadji, 2009; Purna \& Wahyuningsih, 1996; Tashadi et al., 1982; Van der Kroef, 1959, 1960; Wirutomo, 2015a, 2015b; Yulianto, 2017). Some also refer to it as the basic culture (Rahayu et al., 2015) or national culture (Bowen, 1986; Rigg, Allott, Harrison, \& Kratz, 1999) of Indonesia. Likewise, there is another researcher who also mentions it as an Indonesian cultural philosophy (Bowen, 1986). Another researcher mentions it as the strength of the Indonesian culture (Khasanah, 2013). Some also refer to it as the attitude of the Indonesian culture (Abdillah, 2011). Similarly, there is another researcher that refers to Gotong Royong as the Indonesian 
traditional culture (Rochmadi, 2012). There is also one who refers to it as the basis of Indonesian culture (Wawointana, 2001). Finally, there are those who also refer Gotong Royong as the basic characteristics to the Indonesian culture (Suprihatin, 2014).

With all the variants above, Gotong Royong becomes an exalted noble value (Koentjaraningrat, 1985) for the human relationship with each other (Departemen Pendidikan dan Kebudayaan, 1997) because it emphasizes togetherness, tolerance, caring and high respect for each other (Rochmadi, 2012). This is especially advantageous when solving problems confronted in people's daily lives which may influence Indonesia's national identity (Barkin \& Hildebrand, 2014; Lembaga Ketahanan Nasional Republik Indonesia, 1995; Saraswati, 2011; Sood, Chandra, Palmer, \& Molyneux, 2004; Zulkarnain, 2014). Gotong Royong as a noble cultural value, must remain and continue to be a part of life that upholds humanity because in Gotong Royong, each work is carried out jointly regardless of one's position and status, where the work involvement is seen as a process to be in accordance with the expectations of a group work (Newberry, 2007; Pasya, 1987).

The cultural value of Gotong Royong contains four concepts, namely: (1) humans are part of a community, (2) humans depend on all aspects of their fellow human beings, (3) humans must continually maintain good relations with each other, and (4) humans must be fair to each other (Bintari \& Darmawan, 2016). As a cultural value, Gotong Royong places importance on doing hard work together, by showing their care towards each other as a way of supporting collectivism, collaboration and cooperaton (Duwata, 2013). Gotong Royong as a cultural value, therefore, cannot be separated from the activities of the Indonesians' daily lives (Effendi, 2013) because traditionally, most Indonesians depend highly on their neighbors and families. For this reason, most Indonesians rely on their extended families to live satisfactorily rather than relying just on their own nuclear family.

\subsection{Gotong Royong is A Social Solidarity}

Gotong Royong as a sense and a form of social solidarity (Bintari \& Darmawan, 2016; Bowen, 1986; Departemen Pendidikan dan Kebudayaan, 1997; Macrae, 2008; Nasution, 2010; Nobles \& Frankenberg, 2009 ) is used to develop social order and become an institution to mobilize community solidarity and social cohesion. The value and spirit of Gotong Royong is positively utilized in people's lives, in an effort to mobilize community solidarity (Dewantara, 2017b).

Gotong Royong in Indonesia can be understood as the evidence of the ongoing and growing concern of living continuously in humanitarian solidarity (Sutanto, 2018) because it functions to build and instill a sense of solidarity and equality (Koentjaraningrat, 1988) between people. Based on the results of the World Bank's research, the social solidarity of Gotong Royong has had a significant impact on the development process of a number of sectors. For example, in the field of education, students achieve higher grades, teachers are more serious in their work, and school facilities are utilized more properly. First, with students working in groups, assignments are quickly done with better quality because many thinkers are working together to produce the best answer to the question asked by a teacher. Next, teachers become more serious in their work because they are supported by other teachers who would lend a hand voluntarily to making teaching duties done in a more professional manner. Lastly, with a good mutual understanding and cooperation between teachers and students, school facilities can be scheduled to be used to support the better quality of education.

Next, in the health sector, Gotong Royong influences doctors and nurses to play a more active role in paying more attention to their patients' needs. With a good collaboration between doctors and nurses, misunderstandings towards the well being of the patients' health can be minimized. This similar kind of situation, will surely apply in the same way for various other professions (Bendesa, 2009).

\subsection{Gotong Royong is A Principle}

Gotong Royong is the principle of the Indonesian society, who benefits mutual assistance (Braithwaite, 2011a; Van der Kroef, 1959). It became an inspiration of life in Indonesia (Cribb \& Kahin, 2004). In carrying out the cooperation and equality principle of Gotong Royong, people are challenged to demonstrate their togetherness in forms of efficient activities (Mardiasmo \& Barnes, 2015). 


\subsection{Gotong Royong is A Mutual Morality}

Gotong Royong is a mutual morality that based itself with reciprocity (Bowen, 1986; Harnoko \& Salamun, 2016; Newberry, 2007; Nobles \& Frankenberg, 2009; Pierewan \& Sujarwoto, 2010; Pranadji, 2009; Sajogyo \& Sajogyo, 1992; Scott, 1988). When people apply Gotong Royong, it is the same as giving mutual trust to others in having a goal done with success. This mutual workmanship would at the same time produce good morals among the people. Without good morals, a job performance would not be done well in time.

\subsection{Gotong Royong is Active Participation}

Gotong Royong is a form of active participation from each individual to get involved in giving added or positive values to any object, problem or needs of the people around him (Rochmadi, 2012; Simarmata et al., 2017). Active participation can be in the form of support in material, financial, physical, mental, spiritual, skill, constructive thoughts or advice, or to only pray to God (Khasanah, 2013; Pranadji, 2009; Rochmadi, 2012). Active participation in the Gotong Royong process arises from a sense of awareness as part of a meaningful group (Rahayu et al., 2015). Gotong Royong can only occur if people are sincere in being involved in the various activities held in their community (Brahmana, Rochayanti, \& Susilo, 2009).

\subsection{Gotong Royong is Self-Willingness}

Gotong Royong is self-willingness. In Gotong Royong, there is a service and voluntary attitude (Purna \& Wahyuningsih, 1996; Sutowo, 2017; Thomas, Selvadurai, Er, Lyndon, \& Moorthy, 2011). Gotong Royong is a voluntary effort (Bintari \& Darmawan, 2016; Duwata, 2013; Kamsori et al., 2007; Lim, Chan, Alsagoff, \& Ha, 2014; Panglaykim, 1965; Pasya, 1987; Pranadji, 2009; Takwin, 2015) to voluntary work (Bourdieu, 1986; Coleman, 1990; Lin, 2001; Salehudin, Prasad, \& Osmond, 2013) and voluntary activities (Braithwaite, 2011a; Salehudin et al., 2013). Gotong Royong in this case cannot be done if people do not want to volunteer their best abilities and skills for the benefit of others (Bintari \& Darmawan, 2016; Duwata, 2013; Geertz, 1983a; Pasya, 1987; Pranadji, 2009; Sadjad, 2013; Salehudin et al., 2013; Simarmata et al., 2017; Takwin, 2015; Zakaria, 2017).

\subsection{Gotong Royong is A Social Integration}

Gotong Royong is also a form of social integration that is much influenced by a sense of community among citizens that is carried out voluntarily (Pasya, 1987). Gotong Royong, which practices living voluntarily by helping all members of the community according to their limits (Sutrisno, 2017) is a way to show people's integration and care to their immediate society. In Gotong Royong, there is an attitude of doing social service that is integrated with individual's voluntary actions (Purna \& Wahyuningsih, 1996; Sutowo, 2017; Thomas et al., 2011) in order to fulfill the roles needed for optimal results.

\subsection{Gotong Royong is Togetherness}

Gotong Royong is togetherness. Without togetherness there is no Gotong Royong. In Gotong Royong, togetherness must be based on social action and social solidarity. With togetherness in Gotong Royong, everything will work together to achieve the agreed mission (Koentjaraningrat, 1984), therefore, it is a strategy in the pattern of living together (Pasya, 1987). In practicing it, Gotong Royong has a dynamic understanding that describes a business, a charity, a joint work, a struggle to help without force and do hard work for the benefit, goodness and happiness of everyone involved (Adeney-Risakotta, 2014; Godwin, 1991; Latif, 2017; Purna \& Wahyuningsih, 1996; Takwin, 2015). Gotong Royong in living together, aims to achieve the expected results of a common group of interests (Brahmana et al., 2009).

Gotong Royong implies togetherness, equality, justice, caring and is referring to mutual interests (Effendi, 2013; Geertz, 1983a; Pranadji, 2009; Rochmadi, 2012; Sadjad, 2013; Swasono, 2017) because it is also related to the mutual benefits (Samani \& Haryanto, 2011) and shared welfare (Harnoko \& Salamun, 2016; Soekamto, 1986) in bearing and sharing each others' burdens (Braithwaite, 2011b; Geertz, 1983b; Halabi, 2011; Kasali, 2014). Gotong Royong not only implies the carrying out doing heavy work (Agustian, 2016; Bintari \& Darmawan, 2016; Duwata, 2013; Purna \& Wahyuningsih, 1996; Sillifant, 1994), it also implies the solving problems (Khasanah, 2013) of a group work (Dawood, Ghazali, \& Kadir, 
2011; Simarmata et al., 2017) in order to achieve common goals (Agustian, 2016; Bintari \& Darmawan, 2016; Bowen, 1986; Duwata, 2013; Ghazali, 2013; Kwon \& Kim, 2015; Laban, Oue, \& Rampisela, 2015; Masduki, 2014; McCarthy, 2014; Pasya, 1987; Pattiradjawane \& Soebagjo, 2015; Pranadji, 2009; Purna \& Wahyuningsih, 1996; Rahmi, Wibisono, \& Setiawan, 2001; Sugiyanto \& Khamadi, 2011; Sutowo, 2017; Takwin, 2015; Taylor \& Aragon, 1991; Weix, 1996). In other words, Gotong Royong can be interpreted as a joint action that is planned, organized and guided in a certain way to realize agreed goals (Sutowo, 2017). Gotong Royong is done to alleviate work, or the working together of making and providing shared needs (Bintarto, 1980; Tashadi et al., 1982).

Life in togetherness is the reason why Gotong Royong (Laksana, 2016) becomes the spirit for social action and social solidarity. In Gotong Royong, each member of a joint group work has their own duties and roles (Mustaqim, 2013; Surbakti, 2009) to fulfill. This indicates that Gotong Royong is used in completing various jobs that involve common interests (Sudarta, 2003). Gotong Royong, is thus, the human dimension that becomes the bond of togetherness (Dewantara, 2017a, 2017b, 2017c).

\section{Method}

This article reports on the Indonesian cultural value of Gotong Royong by use of library research in its method. With library research, data about the meaning, history and application of Gotong Royong is obtained by tracking articles, books, or journals either in printed form or from online resources available through Google Scholar and several Journal Websites subscribed by Gadjah Mada University.

\section{Discussion}

\subsection{The Exercise of Gotong Royong in Indonesia's Multi-Cultures}

As learned from the previous readings, Gotong Royong is a cultural value that is handed down from one generation to another generation that it becomes a habitual trait by anyone born in Indonesia. It is a common thing to do for Indonesians to give a helping hand if anyone around the neighborhood needs help. In this way, people would readily do favors for others when experiencing trouble, without being asked (Ariyantoni, 2014; Sari, Darmawan, \& Wahyuningrum, 2016; Soekamto, 1986). This indicates that Gotong Royong has been deeply rooted in the Indonesian culture and and developed by the Indonesian society for some time (Effendi, 2013).

Gotong Royong is a cultural value for any Indonesian, regardless of race, gender and ethnicity. Based on library research, it is found in history that Gotong Royong has existed since the Neolithic period, which is in the beginning of 6000 B.C. The earliest Gotong Royong activity was the communal lifting and transfer of the Menhir stone from one person to another, due to the only kind of machinery being the human beings themselves, who can build up a worshipping landmark for the ancestral spirits in Nias (Mulia, 1980; Yondri, 2017).

Gotong Royong has also existed in Tana Toraja, through a stone pulling ceremony. The pulling of the stone was for it to be erected as a mark of where a deceased figure was rested in peace. A similar thing is also evident in Sumba, West Timor and Flores (Sukendar, 1996; Yondri, 2017) where heavy stones are erected as a sign for a burial ground. In Java, the heavy stones are not only erected but also given some carvings on them for decoration.

Gotong Royong has been known to the people of the archipelago since 117-45 B.C. when residents of Gunung Padang, Cianjur Regency, West Java, built a punden site in the terraces of Gunung Padang (Yondri, 2017). The Gotong Royong system has also been institutionalized in the archipelago community ever since the days of the Hindu Kingdom in Java, such as the Ancient Mataram (732-928 A.D.) and Majapahit (1293-1527) kingdom (Suwondo, 1982).

\subsection{Gotong Royong in Indonesia's Battlefield}

Historical evidence of how ancient the Gotong Royong has been exercised by the Indonesian people is in the Youth Pledge on October $28^{\text {th }} 1928$.The pledge that claims Indonesia to be a nation of people, who are 
embraced in one unity in language and homeland, is actually a promise from the Indonesian people to always be in unison and help each other based on the principle of Gotong Royong, regardless of religious, ethnic, racial, and other background differences (Pranowo, 2010; Simarmata et al., 2017).

History also records that Indonesia's independence on August 17th 1945 was achieved by the Gotong Royong of all of the Indonesian people (Pranowo, 2010) to sacrifice their lives by mutually working together to drive away the nation's invaders (Widadi, 2012). This was done in order to achieve the communal dream of being independent (Soepandji, 2013) from the invaders.

The Battle of Surabaya on the $10^{\text {th }}$ of November in 1945 also contained the spirit of Gotong Royong. This can be seen in the speech excerpt of the key figure in the battle, namely Sutomo (Bung Tomo), which showed his hope that young people from all over Indonesia would work together to help the youth in Surabaya to be free from outside invaders.

Each of the above battles have proved to the world that the Indonesian Proclamation of Independence was not just any kind of statement, but instead, it was a statement supported by strong social solidarity, which was manifested in the cultural value of Gotong Royong (Pranowo, 2010).

\subsection{Soekarno and The Ideology, Motto, and Democratic Gotong Royong Life in Indonesia}

Soekarno, the first President of the Republic of Indonesia in 1945-1967 (Latif, 2014) informed that the Indonesian ideology, Pancasila was initiated as a Trisila. It was later developed into the Ekasila of Gotong Royong (Abdillah, 2011; Dewantara, 2017a, 2017b, 2017c; Kusuma, 2004; Lembaga Ketahanan Nasional Republik Indonesia, 2015b; Mahar \& Lee, 2017; Setiawan, 2013; Simarmata et al., 2017; Suryohadiprojo, 2016; Triwidodo, 2017; Zakaria, 2017). In his speech, delivered in front of the BPUPK (Investigating Committee for Preparatory Work for Independence) on June $1^{\text {st }}, 1945$, he stated “... maybe there are some of you who don't like this number five? I may squeeze it, so there are only three. You may ask me, what is the third squeeze? For decades I have thought about it. The answer is it is basically the basis of our independence, Weltanschauung (ideology / philosophy of life). The first two basics is covering our nationalities and internationalism. When nationality and humanity are squeezed into one: that is what I used to call as socio-nationalism... and democracy that is not Western democracy, but the politiekekonomische demokratie (political-economic democracy), namely the politieke demokratie (political democracy) with sosiole rechtvaardigheid (social justice), democracy with prosperity, can also all be squeezed into one. That's what I would call as social-democracy. Thus, what is left is the Godhead that respects one another. So, the origin of the five has become three: socio-nationalism, socio-democracy, and the Godhead. If you are happy with the these three, you may take these three precepts. But maybe not all of you are happy with this Trisila, and ask for only one, just one precept, right? Alright, I'll make into one. I will compile all into one. What is that one? As I said earlier, we established Indonesia as a country in which we all have to support. All for all! Not Christian for Indonesia, not Islam for Indonesia, not Hadikoesoemo for Indonesia, not Van Eck for Indonesia, not rich Nitisemito for Indonesia, but Indonesia for Indonesia, all for all! If I squeeze the five into three, and the three become one, then one genuine Indonesian word can be obtained, namely the word Gotong Royong. The Indonesian country that we have founded must be a Gotong Royong country. What a great thing! Gotong Royong country!" (Bahar, Sinaga, \& Kusuma, 1993; Darmaputera, 1989; Latif, 2014; Muryanti, 2014; Pranadji, 2009; Pranowo, 2010; Rochmadi, 2012; Sadjad, 2013).

It becomes clear from hereafter that Soekarno's speech above about the basis of the five principles in Pancasila is indeed Gotong Royong. The spirit of Gotong Royong, became the conception of the state ideology. The five main principles, which united Indonesia and became the direction for people to live in peace and harmony in togetherness was clearly imbedded in Pancasila.

As explained above, the five principles were developed through the spirit of Gotong Royong. This means that the Godhead principle must put forth the importance of working together. In other words, the Godhead must be a culturally-minded, tolerant being who fosters tolerance among religious people, rather than a Godhead that attacks and excommunicates among religions and beliefs that are plural in Indonesia. With this in mind, the universal principle of Humanity must, therefore, have the Gotong Royong spirit of establishing a civilized society and, not humanity society which defeats from humanity with its colonizing, oppressive and exploitative character. As a consequence of the above characteristics, the Indonesian motto of Bhineka Tunggal Ika (unity in diversity) has Gotong Royong spirit within it.

The Indonesian definition of democracy must also have Gotong Royong spirit because it must help develop consensus agreements in the multicultural country of Indonesia. Indonesian democracy should not be dictated by the majority or minority of elite capitalists (minorocracy). The principle of justice must, henceforth, be in the Indonesian Gotong Royong spirit, in order todevelop active participation and 
emancipation in the economic field, and not a vision of prosperity based on individualcapitalism. Democracy, in other words, should not restrict, such as that found in the system of ethatism, makes the state becomes the center of all power (Latif, 2017; Muryanti, 2014). Soekarno stated, "If we really want to base our country on the notion of Gotong Royong, we must eliminate any individualism and liberalism from it" (Mahkamah Konstitusi Republik Indonesia, 2010a). In brief, Soekarno emphasized that the basic principles of Pancasila, i.e. from Godhead, Humanity, Unity, Popularism, and Justice, are within Gotong Royong (Pranowo, 2010). Soekarno's Mandate of the Proclamation on August 17th 1959 reemphasized the concept of Gotong Royong through its dynamic characteristics of working together, with great energy, and giant struggle, and so on.

One of the distinctive shouts of this dynamic Gotong Royong activity is the "holopis-kuntul-baris", which literally mean, "The people must all be brought together in this giant struggle!" (Dewantara, 2017a). The Gotong Royong spirit must be a show of the cooperation and typical mutual assistance Indonesia can provide to each other (Darmaputera, 1989). For this reason, according to Soekarno, Gotong Royong is the original value of Indonesia (Dewantara, 2017a, 2017b, 2017c) that was extracted from the history of the Indonesian people (Bintari \& Darmawan, 2016; Kaelan, 2013; Khasanah, 2013). By showing Gotong Royong behavior, people have the freedom of exoressing their aspirations, togetherness and social solidarity (Bintari \& Darmawan, 2016) which are achieved successfully only if aone effort, one charity, and one work is done by working hard and sweating together (Bahar et al., 1993; Effendi, 2013; Kusuma, 2004; Latif, 2015).

During his Presidency, Soekarno gave a special view that the national identity of Indonesia and the work ethic of the Indonesian people were Gotong Royong (Alfian, 2018; Pranowo, 2010). Sukarno said that the soul of the Indonesian spirit is Gotong Royong (Mahar \& Lee, 2017). To make sure that the importance of Gotong Royong was not overlooked, he named some of his governmental departments with Gotong Royong. Examples were the DPR-Gotong Royong (Pranadji, 2009; Pranowo, 2010; Rochmadi, 2012). Kosgoro (Gotong Royong Multipurpose Cooperative/ Koperasi Serba Usaha Gotong Royong) and the Gotong Royong Family Assembly (Musyawarah Kekeluargaan Gotong Royong-MKGR) (Bowen, 1986; Rigg et al., 1999).

\subsection{Gotong Royong Interpretations by Other Indonesians Leaders}

Muhammad Hatta, the first Vice President of the Republic of Indonesia in 1945-1956 explored the collaborative and collective roots of the Indonesian Gotong Royong (Simarmata et al., 2017). In support with Soekarno, Hatta also said that Gotong Royong is the foundation of the Indonesian democracy (Dewantara, 2017a, 2017b, 2017c). Being a large, and broad multicultural country, Indonesia is managed under the Gotong Royong principle by involving regional participation in the economic, political and socio-cultural sectors to empower the kinds of diversity found in respective regional potency (Kusuma, 2004).

Soepomo, who is the first Indonesian Minister of Justice of the Republic of Indonesia in 1949-1950, also supported Mohammad Hatta, and Mohammad Yamin, the fourteenth Minister of Information of the Republic of Indonesia in 1962, ninth Minister of Education and Culture of the Republic of Indonesia in 1953-1955 and the sixth Minister of Justice of the Republic of Indonesia in 1951. They all said that Gotong Royong is the typical characteristic of Indonesian society.

In his speech on May 31st 1945 Soepomo put forward the idea of Gotong Royong as the basis of the state. He said, "In an atmosphere of unity between the people and their leaders, among the people, each group is surrounded by Gotong Royong" (Bahar et al., 1993; Mahkamah Konstitusi Republik Indonesia, 2010b). In fact, Soekarno, Muhammad Yamin, Soepomo, and Mohammad Hatta agree to Gotong Royong as the basic nature of Indonesian people's social lives' interaction (Dewantara, 2017a, 2017b, 2017c).

Ruslan Abdulgani, who is the ninth Minister of Foreign Affairs in 1956-1957 and the fifteenth Minister of Information in 1963-1964 of the Republic of Indonesia, said that the ideals of people's sovereignty were an affirmation of the Indonesian's Gotong Royong life principle that is led by a desire to give the best service for those having common interests (Mahkamah Konstitusi Republik Indonesia, 2010a) .

Soeharto, the second President of the Republic of Indonesia in 1967-1957 said that Gotong Royong is a distinctive characteristic and pattern of life of the Indonesian people. Gotong Royong has an important place in the Broad Guidelines of the State (GBHN-Garis-garis Besar Haluan Negara) so that this inheritance must be preserved for the success of National Development (Bintarto, 1980). At the DPR-Gotong Royong session on August 16 1967 Soeharto also expressed his view that politics based on Gotong Royong builds good neighborhood relationships by being able to live together peacefully, without harming national interests, and regardless of the political system adopted by each Indonesian citizen 
(Pattiradjawane \& Soebagjo, 2015). In his state address on GBHN on August 16 $6^{\text {th }}$ 1978, he also emphasized that Gotong Royong is a distinctive characteristic and lifestyle of the Indonesian people. This was then followed up at the Cultural Development Seminar in the context of National Development in July 1978 by including Gotong Royong as a manifestation of the spirit of kinship in the vision of the Pancasila culture.

During his Presidency, Suharto included the value of Gotong Royong as one of the seven principles of the Indonesian national development. This is stated in the TAP MPR No. IV/MPR/1978 concerning the Broad Guidelines of the State which stated that, "the principle of joint effort is that efforts to achieve the ambitions and aspirations of the nation must be a joint effort of the nation by all people carrying out the principles of Gotong Royong" (Dewantara, 2017a, 2017b, 2017c). In addition to this, the 1945 Constitution of the Republic of Indonesia, of Chapter XIII on Education and Culture, article (Firmanzah, 2017) paragraph 1, year 2002 states that the state promotes Indonesian national culture amidst world civilization by ensuring people's freedom in maintaining the development of its cultural values. These give proof that the Gotong Royong that has become the national culture of Indonesia (Mustaqim, 2013) needs to be maintained and preserved, so, in the future, it continues to exist as the national identity of Indonesia (Yuniarti, 2015).

\section{Conclusion}

From the discussion above on the meaning, interpretations, and history of Gotong Royong, this article proves that Gotong Royong is an essential cultural value for the Indonesian society (Khasanah, 2013). The effort of informing how the word Gotong Royong became the soul of the former President Soekarno's thoughts and actions in order to frame up Indonesia's Proclamation of Independence, Pancasila, Bhineka Tunggal Ika and living a democratic life in harmony, is a significant history and culture for Indonesia. How Gotong Royong is perceived by scholars and other previous leaders of Indonesia is worthy to be written in this article, so that the actual meaning of Gotong Royong is not deviated by irresponsible people.

In summary, this article has contributed in the clearer background of what Gotong Royong is for Indonesians, so it is easier to understand and put to practice by future generations. Not only is Gotong Royong a spirit of togetherness for Indonesia's social harmony, it is a cultural value that must be maintained and passed down to others. The good mutual understanding between each Indonesian in order to achieve unity within the diverse multi-cultures of Indonesia cannot happen in harmony, if the Indonesian citizens do not clearly know the concept and history of Gotong Royong. The solid and good cooperation that Indonesia has from living in Gotong Royong, it is projected that future generations of Indonesia can always find solutions to whatever obstacles they may encounter. In conclusion, like expressed by Soekarno, all in all is only possible when living in Gotong Royong!

\section{References}

Abdillah, B. (2011). Gotong Royong Cermin Budaya Bangsa Dalam Arus Globalisasi. Yogyakarta: AMIKOM.

Adeney-Risakotta, B. (2014). Dealing with Diversity Religion, Globalization, Violence, Gender and Disaster in Indonesia. Geneva: Globethics.net.

Agustian, A. (2016). Revolusi mental berbasis ESQ (Kecerdasan Emosi \& Spiritual). Jakarta: Arga Tilanta.

Alfian, M. A. (2018). Menggali etos kerja Pancasila. KOMPAS. Retrieved from https://kompas.id/baca/opini/2018/06/02/menggali-etos-kerja-pancasila/

Ancok, D. (2004). Psikologi Terapan: Mengupas Dinamika Kehidupan Umat Manusia. Yogyakarta: Penerbit Darussalam.

Ariyantoni, D. (2014). Budaya Gotong Royong Bangsa Indonesia sebagai Common Identity dalam Wawasan Nusantara. Universitas Gadjah Mada, Yogyakarta. 
Bahar, S., Sinaga, N. H., \& Kusuma, A. B. (1993). Risalah Sidang Badan Penyelidik Usaha-Usaha Persiapan Kemerdekaan Indonesia (BPUPKI) dan Panitia Persiapan Kemerdekaan Indonesia (PPKI)(Effendi, 2013) Mei-19 Agustus 1945. Jakarta: Sekretariat Negara Republik Indonesia.

Barkin, G., \& Hildebrand, V. M. (2014). Midwife Radio: The Entangled Trajectories of Global Health Programming, Broadcast Media, and the Indonesian State. Anthropological Quarterly, 87(4), 1105-1135. https://doi.org/10.1353/anq.2014.0061

Bendesa, I. (2009). Pembangunan dalam Perspektif Pertahanan Negara: Peran Pemerintah Daerah. Seminar Nasional Tentang Pemberdayaan Wilayah Pertahanan Melalui Binter Bersama Seluruh Komponen Bangsa Dalam Rangka Mengamankan Kepentingan Nasional Di Universitas. Makalah disampaikan pada Seminar Nasional tentang Pemberdayaan Wilayah Pertahanan Melalui Binter Bersama Seluruh Komponen Bangsa dalam Rangka Mengamankan Kepentingan Nasional di Universitas.

Bintari, P., \& Darmawan, C. (2016). Peran Pemuda Sebagai Penerus Tradisi Sambatan Dalam Rangka Pembentukan Karakter Gotong Royong. Jurnal Pendidikan Ilmu Sosial, 25(1).

Bintarto, R. (1980). Gotong Royong: Suatu Karakteristik Bangsa. Surabaya: Bina Ilmu.

Bourdieu, P. (1986). The Forms of Capital. In J. G. Richardson (Ed.), Handbook of Theory and Research for the Sociology of Education (pp. 241-258). New York: Greenwood Press.

Bowen, J. R. (1986). On the Political Construction of Tradition: Gotong Royong in Indonesia. The Journal of Asian Studies, 45(3), 545-561. https://doi.org/10.2307/2056530

Brahmana, E. B., Rochayanti, C., \& Susilo, M. E. (2009). Nilai-nilai gotong-royong dalam tari mbuah page (analisis semiotika nilai-nilai gotong-royong dalam tari mbuah page pada acara adat merdang-merdem di Desa Perbesi Kecamatan Tigabinanga Kabupaten Karo Sumatera Utara). Jurnal Ilmu Komunikasi, 7(1).

Braithwaite, J. (2011a). Anomie and Violence in Indonesia and Timor-Leste, 1997-2009. Asian Journal of Criminology, 6(1), 51-68. https://doi.org/10.1007/s11417-010-9087-2

Braithwaite, J. (2011b). Partial truth and reconciliation in the longue durée. Contemporary Social Science, 6(1), 129-146. https://doi.org/10.1080/17450144.2010.534498

Coleman, J. (1990). Foundations of Social Theory. Cambridge: Belkp Press.

Cribb, R., \& Kahin, A. (2004). Historical dictionary of Indonesia (2nd ed). In torical dictionary of Indonesia (2nd ed). Historical Dictionaries of Asia, Oceania, and the Middle East. No. 51. Maryland: The Scarecrow Press, Inc.

Darmaputera, E. (1989). Pancasila: Identitas dan Integritas Bangsa Indonesia. Jakarta: Gunung Mulia.

Dawood, S. R. S., Ghazali, S., \& Kadir, S. M. A. (2011). Preserving village identity in a globalizing city space: The case of Kampung Dodol, George Town, Penang, Malaysia. International Journal of Arts \& Sciences, 4(23), 219-230.

Departemen Pendidikan dan Kebudayaan. (1997). Pembinaan Nilai-Nilai Budaya Melalui Permainan Rakyat di Daerah Jambi. Jambi: Departemen Pendidikan dan Kebudayaan.

Dewantara, A. W. (2017a). Alangkah Hebatnya Negara Gotong Royong: Indonesia dalam Kacamata Soekarno. Yogyakarta: Kanisius.

Dewantara, A. W. (2017b). Diskursus filsafat Pancasila Dewasa Ini. Yogyakarta: Kanisius.

Dewantara, A. W. (2017c). Pendidikan Nilai Gotong-Royong Sebagai Strategi Ketahanan Nasional. Seminar Nasional KeIndonesiaan II Tahun 2017: Strategi Kebudayaan Dan Tantangan Ketahanan Nasional Kontemporer. Semarang: Universitas PGRI. 
Djamari. (2016). Penanaman Sikap Gotong Royong Dalam Kegiatan Ekstrakurikuler Pramuka Di SDN 3 Kronggen Grobogan. Universitas Muhammadiyah Surakarta.

Duwata, N. (2013). Aktualisasi nilai kekeluargaan (persaudaraan) dan nilai kegotongroyongan dalam permainan tarik tambang pada warga masyarakat RT 24 RW 06 Sidikan Umbulharjo Yogyakarta tahun 2012. Jurnal Citizenship, 2(1).

Effendi, T. N. (2013). Budaya Gotong-Royong Masyarakat dalam Perubahan Sosial Saat Ini. Jurnal Pemikiran Sosiologi, 2(1), 1-18.

Fajarini, U. (2014). Peranan kearifan lokal dalam pendidikan karakter. SOSIO DIDAKTIKA: Social Science Education Journal, 1(2), 123-130. https://doi.org/10.15408/sd.v1i2.1225

Firmanzah. (2017). Mengapa budaya penting bagi ekonomi? In S. Sularto \& A. Paramita (Eds.), Nilai Keindonesiaan: Tiada bangsa besar tanpa budaya kokoh. Jakarta: PT Kompas Media Nusantara.

Geertz, C. (1983a). From The Native's Point of View: On The Nature of Anthropological Knowledge. In C. Geertz (Ed.), In Local Knowledge: Further Essays in Interpretive Anthropology (pp. 55-70). New York: Basic Books.

Geertz, C. (1983b). Local Knowledge: Further essays in interpretive antrophology. New York: Basic Books.

Ghazali, S. (2013). Sense of place and the politics of "Insider-Ness" in Villages undergoing transition: the case of City Kampung on Penang Island. In Cleavage, Connection and Conflict in Rural, Urban and Contemporary Asia (pp. 117-142). Dordrecht: Springer.

Godwin, R. K. (1991). Charges for merit goods: Third world family planning. Journal of Public Policy, 11(4), 415-429. Retrieved from https://www.jstor.org/stable/4007464

Gunardo, R. B. (2013). Karakter gotong royong warga dalam menghadapi bencana banjir lahar dingin merapi di Kota Yogyakarta. Jurnal Penelitian Humaniora, 18(2), 156-165.

Halabi, S. F. (2011). Participation and the right to health: Lessons from Indonesia. Health and Human Rights, 11(1), 49-59. Retrieved from https://www.ncbi.nlm.nih.gov/pubmed/20845850

Hardiman, B. (1980). Kritik Atas Patologi Modernitas dan Post Modernisme. Driyakarya, 2(19), $42-63$.

Harnoko, D., \& Salamun. (2016). Biografi Widayat Djiang: Sebuah Sketsa Kehidupan Dalang Peranakan Tionghoa. Kementerian Pendidikan dan Kebudayaan (Kementerian Pendidikan dan Kebudayaan, Ed.). Yogyakarta: Balai Pelestarian Nilai Budaya.

Hofstede, G. (1994). Cultures and organizations: software of the mind. London: Harper-Collins Publishers.

Julaikha, S., \& Bahri, S. (2014). Nilai-nilai gotong-royong dalam masyarakat petani padi sawah Di Desa Sungai Siput Kecamatan Siak Kecil Kabupaten Bengkalis. Jom FISIP, 1(2).

Kaelan. (2013). Negara Kebangsaan Pancasila. Yogyakarta: Paradigma.

Kamsori, M. E., Santosa, A. B., \& Moe'is, S. (2007). Dinamika Kehidupan Masyarakat Perkotaan (Edisi 3). Bandung: Anggita Pustaka Mandiri.

Kasali, R. (2014). From one dollar to billion dollars company. Jakarta: Penerbit buku KOMPAS.

KBBI. (2002). Kamus Besar Bahasa Indonesia. Jakarta: Balai Pustaka.

Khasanah, N. (2013). Pengejawantahan nilai-nilai dalam pengembangan budaya gotong royong di era digital. Edukasi, 1(1), 92-108. 
Koentjaraningrat. (1961). Gotong Rojong: Some Social Anthropological Observation on Practices in Two Villages of Central Java (C. Holt, Ed.). United Kingdom: Equinox Publishing.

Koentjaraningrat. (1984). Masyarakat Desa di Indonesia. Jakarta: Lembaga Penerbit Universitas Indonesia.

Koentjaraningrat. (1985). Javanese Culture. Oxford: Oxford University Press.

Koentjaraningrat. (1988). The Indonesian mentality and development. Journal of Social Issues in Southeast Asia, 3(2), 107-133. Retrieved from https://www.jstor.org/stable/41057106

Kusuma, A. B. (2004). Lahirnya Undang-Undang Dasar 1945. Jakarta: Pusat Studi Hukum Tatanegara.

Kwon, H., \& Kim, W. (2015). The Evolution of Cash Transfers in Indonesia: Policy Transfer and National Adaptation. Asia \& the Pacific Policy Studies, 2(2), 425-440. https://doi.org/10.1002/app5.83

Laban, S., Oue, H., \& Rampisela, A. (2015). Irrigation Practice and its Effects on Water Storage and Groundwater Fluctuation in the First Dry Season in the Rice Cultivation Region, South Sulawesi, Indonesia. Procedia Environmental Sciences, 28, 271-279. https://doi.org/10.1016/j.proenv.2015.07.035

Laksana, I. K. D. (2016). Ungkapan Tradisional: Makna dan Fungsinya dalam Menjaga Negara Kesatuan Republik Indonesia. In I. K. Sudewa (Ed.), Seminar Nasional Sastra dan Budaya (pp. 27-28). Denpasar.

Latif, Y. (2014). Mata Air Keteladanan: Pancasila Dalam Perbuatan. Jakarta: Mizan.

Latif, Y. (2015). Keharusan revolusi mental. In J. Sinamo (Ed.), Menggulirkan Revolusi Mental di Berbagai Bidang. Jakarta: Institut Darma Mahardika.

Latif, Y. (2017). Relevansi Pancasila dalam hidup kekinian. In Sularto \& A. Paramita (Eds.), Nilai Keindonesiaan: Tiada Bangsa Besar Tanpa Budaya Kokoh. Jakarta: PT Kompas Media Nusantara.

Lembaga Ketahanan Nasional Republik Indonesia. (1995). Wawasan Nusantara. Jakarta: PT Balai Pustaka.

Lembaga Ketahanan Nasional Republik Indonesia. (2015a). Modul Bidang Studi Kepemimpinan. Sub Bidang Studi Kepemimpinan Nasional Program Pendidikan Singkat Angkatan (PPSA) XX. Jakarta: Lembaga Ketahanan Nasional RI.

Lembaga Ketahanan Nasional Republik Indonesia. (2015b). Modul Bidang Studi Pancasila Dan UUD Negara RI 1945. Sub Bidang Studi UUD NRI 1945 Dan Permasalahannya. Program Pendidikan Singkat Angkatan (PPSA) XX. In Sub Bidang Studi UUD NRI. Jakarta: Lembaga Ketahanan Nasional Republik Indonesia.

Lim, J., Chan, M. M. H., Alsagoff, F. Z., \& Ha, D. (2014). Innovations in non-communicable diseases management in ASEAN: a case series. Global Health Action, 7(1), 25110. https://doi.org/10.3402/gha.v7.25110

Lin, N. (2001). Social Capital: A Theory of Social Structure and Action. Cambridge, UK.: Cambridge University Press.

Macrae, G. (2008). Could the system work better? Scale and local knowledge in humanitarian relief. Development in Practice, 18(2), 190-200. https://doi.org/10.1080/09614520801898970

Mahar, M. I., \& Lee, A. (2017). Visi persatuan pendiri bangsa: Membaca Indonesia. Retrieved March 31, 2019, from https://kompas.id/baca/polhuk/2017/03/31/visi-persatuan-pendiri-bangsa/

Mahkamah Konstitusi Republik Indonesia. (2010a). Naskah Komprehensif Perubahan Undang-Undang Dasar Negara Republik Indonesia Tahun 1945: Latar Belakang, Proses, dan Hasil Pembahasan. In Buku I. Edisi Revisi. Jakarta: Sekretariat Jenderal dan Kepaniteraan Mahkamah Konstitusi. 
Mahkamah Konstitusi Republik Indonesia. (2010b). Naskah Komprehensif Perubahan Undang-Undang Dasar Negara Republik Indonesia Tahun 1945: Latar Belakang, Proses, dan Hasil Pembahasan. In Buku II: Sendi-sendi/Fundamental Negara. Jakarta: Sekretariat Jenderal dan Kepaniteraan Mahkamah Konstitusi.

Marcillia, S. R., \& Ohno, R. (2012). Learning from Residents' Adjustments in Self-Built and Donated Post Disaster Housing After Java Earthquake 2006. Social and Behavioral Sciences, 36, 61-69.

Mardiasmo, D., \& Barnes, P. (2015). Community Response to Disasters in Indonesia: Gotong Royong; a Double Edged-Sword. In P. H. Barnes \& A. Goonetilleke (Eds.), Proceedings of the 9th Annual International Conference of the International Institute for Infrastructure Renewal and Reconstruction, Queensland (pp. 301-307). Brisbane, Australia: University of Technology.

Masduki. (2014). Filosofi interaksi sosial lintas agama: Wawasan Islam toleransi. Media Komunikasi Umat Beragama, 6(1).

McCarthy, J. F. (2014). Using community led development approaches to address vulnerability after disaster: Caught in a sad romance. Global Environmental Change, 27, 144-155. https://doi.org/10.1016/j.gloenvcha.2014.05.004

Mulia, R. (1980). Nias: The Only Order Megalithic Tradition in Indonesia. Jakarta: Pusat Penelitian Arkeologi Nasional.

Muryanti. (2014). Revitalisasi gotong royong: Penguat persaudaraan masyarakat Muslim di pedesaan. Sosiologi Reflektif, 9(1).

Mustaqim, A. H. (2013). Gotong Royong Dalam Dwilogi Padang Bulan dan Cinta Di Dalam Gelas Karya Andrea Hirata (Sebuah Kajian Sosiologi Sastra). WANASTRA, 4(1).

Nasution, Z. (2010). Konflik dan Lunturnya Solidaritas Sosial Masyarakat Desa Transisi. Retrieved June 15, 2019, from http://berkarya.um.ac.id/2010/02/konflik-dan-lunturnya-solidaritas-sosial

Newberry, J. (2007). Rituals of Rule in the Administered Community: The Javanese Slametan Reconsidered. Modern Asian Studies, 41(6), 1295-1329. https://doi.org/10.1017/S0026749X06002575

Nobles, J., \& Frankenberg, E. (2009). Mothers' Community Participation and Child Health. Journal of Health and Social Behavior, 50(1), 16-30. https://doi.org/10.1177/002214650905000102

Panglaykim, J. (1965). Worker-Management Councils in Indonesia. World Politics, 17(2), 243-255. https://doi.org/10.2307/2009350

Panjaitan, M. (2013). Dari Gotong Royong Ke Pancasila. Jakarta: Jala Permata Aksara.

Pasya, G. K. (1987). Gotong Royong Dalam Kehidupan Masyarakat. Prisma, 3, 18-27.

Pattiradjawane, R. L., \& Soebagjo, N. (2015). Global maritime axis: Indonesia, China, and a new approach to Southeast Asian regional resilience. International Journal of China Studies, 6(2), 175-185.

Pierewan, A. C., \& Sujarwoto. (2010). Gotong Royong and Mental Health in Indonesia. The First International Conference Of Indigenous \& Cultural Psychology. Yogyakarta: Universitas Gadjah Mada.

Pranadji, T. (2009). Penguatan Kelembagaan Gotong Royong dalam Perspektif Sosio Budaya Bangsa. Jurnal Forum Penelitian Agro Ekonomi, 27(1), 61-72.

Pranowo, M. B. (2010). Multidimensi Ketahanan Nasional. Jakarta: Pustaka Alvabet.

Prawiroatmodjo, S. (1981). Bausastra Jawa-Indonesia (Javanese-Indonesian Dictionary). Jakarta: Gunung Agung. 
Purna, I. M., \& Wahyuningsih, R. A. (1996). Macapat dan Gotong Royong. Jakarta: CV Putra Sejati Raya.

Raharjo, S. B. (2010). Pendidikan Karakter Sebagai Upaya Menciptakan Akhlak Mulia. Jurnal Pendidikan Dan Kebudayaan, 16(3), 229-238.

Rahayu, S., Ludigdo, U., Irianto, G., \& Nurkholis. (2015). Budgeting of school operational assistance fund based on the value of gotong royong. Social and Behavioral Sciences, 211, 364-369.

Rahmi, D. H., Wibisono, B. H., \& Setiawan, B. (2001). Rukun and Gotong Royong: Managing Public Places in an Indonesian Kampung. In P. Miao (Ed.), Public Places in Asia Pacific Cities: Current Issues and Strategies (pp. 119-134). Dordrecht: Kluwer Academic Press.

Rigg, J., Allott, A., Harrison, R., \& Kratz, U. (1999). Understanding languages of modernization: a southeast asian view. Modern Asian Studies, 33(3), 581-602.

Rochmadi, N. (2012). Gotong royong sebagai common identity dalam kehidupan bertetangga negara-negara Asean. Jurnal Forum Sosial Universitas Negeri Malang, 9(40).

Sadjad, S. (2013). Karakter bangsa. KOMPAS.

Sajogyo, \& Sajogyo, P. (1992). Sosiologi Pedesaan. Yogyakarta: Gadjah Mada University Press.

Salehudin, M. S., Prasad, D., \& Osmond, P. (2013). A Field Survey Of Local Community Empowerment Initiatives At Selected Resort In Malaysia. Conference of the International Journal of Arts \& Sciences, $6(1), 445-452$.

Samani, M., \& Haryanto. (2011). Pendidikan Karakter: Konsep Dan Model. Bandung: PT Remaja Rosdakarya.

Saraswati, R. (2011). Budaya Gotong Royong Dan Implikasinya Terhadap Ketahanan Sosial Budaya Di Era Globalisasi (Studi Kasus Pada Masyarakat Cisaranten Endah). Universitas Gadjah Mada.

Sari, S., Darmawan, E., \& Wahyuningrum, S. H. (2016). The role of social cohesion as strategy for reducing tourism spatial conflict. DIMENSI-Journal of Architecture and Built Environment, 43(2), 131-136. https://doi.org/https://doi.org/10.9744/dimensi.43.2.131-136

Scott, J. (1988). Moral Ekonomi Petani. jakarta: LP3ES.

Setiawan, D. (2013). Peran pendidikan karakter dalam mengembangkan kecerdasan moral. Jurnal Pendidikan Karakter Tahun III, 1, 53-63. https://doi.org/https://doi.org/10.21831/jpk.v0i1.1287

Sillifant, J. (1994). Lokakarya Dusun: Building Community Self-Reliance And Community Input To The Development Process In Central Sulawesi, Indonesia. Peace Research, 26(1), 41-59.

Simarmata, H. T., Sunaryo, F., Purnama, C. S., Susanto, A., Nurjanah, N., Rizal, G. N., \& Sapei, A. (2017). Indonesia: Emerald Chain of Tolerance (1st ed). Jakarta: Pusat Studi Islam dan Kenegaraan Indonesia (PSIK-Indonesia).

Soekamto, S. (1986). Sosiologi Suatu Pengantar. Jakarta: CV. Rajawali.

Soepandji, B. S. (2013, March). Menyiapkan Pemimpin yang Berkarakter. Swantara: Majalah Triwulan Lemhanas RI. No.4. Tahun I.

Sood, S., Chandra, U., Palmer, A., \& Molyneux, I. (2004). SIAGA Behavior Change Campaign in Indonesia with Population-Based Survey Results. Baltimore: Johns Hopkins Bloomberg School of Public Health.

Sudarta, W. (2003). Peranan wanita dalam pembangunan berwawasan gender. Jurnal Studi Jender Srikandi, $3(1), 1-12$. 
Sugiyanto, \& Khamadi. (2011). Perancangan Game Edukasi "Semangat Si Semut', Sebagai Media Untuk Menanamkan Semangat Gotong Royong Pada Anak Usia Din.” Techno.COM, 10(1), 35-40.

Sukendar, H. (1996). Dinamika dan Kepribadian Bangsa yang Tercermin dari Tradisi Megalitik di Indonesia. In Jurnal Arkeologi Indonesia (Vol. 2). Jakarta: Pusat Penelitian Arkeologi Nasional.

Suprihatin, I. (2014). Perubahan Perilaku Bergotong Royong Masyarakat Sekitar Perusahaan Tambang Batubara Di Desa Mulawarman Kecamatan Tenggarong Seberang. Journal Sosiatri, 1(3), 63-77.

Surbakti, R. (2009). Memahami ilmu politik. Jakarta: Grasindo.

Suryohadiprojo, S. (2016). Budaya Gotong Royong dan Masa Depan Bangsa. Jakarta: PT Kompas Media Nusantara.

Sutanto, L. (2018). Posisi Adab Indonesia. Retrieved March 5, 2019, from Kompas website: https://kompas.id/baca/opini/2018/03/15/posisi-adab-indonesia/

Sutowo, P. (2017). Kebudayaan sebagai rujukan dasar kehidupan kebangsaan. In N. St. Sularto \& A. Paramita (Eds.), Nilai Keindonesiaan: Tiada Bangsa Besar Tanpa Budaya Kokoh. Jakarta: PT Kompas Media Nusantara.

Sutrisno, F. X. M. (2017). Rumah Makna. In St. Sularto \& A. Paramita (Eds.), Nilai Keindonesiaan: Tiada Bangsa Besar Tanpa Budaya Kokoh. Jakarta: PT Kompas Media Nusantara.

Suwondo, B. (1982). Sistem Gotong royong dalam masyarakat pedesaan daerah DIY. Jakarta: Depdikbud.

Swasono, S. E. (2017). Demokrasi Ekonomi Untuk Keberdaulatan Dan Kemandirian. In Sularto \& A. Paramita (Eds.), Nilai Keindonesiaan: Tiada Bangsa Besar Tanpa Budaya Kokoh. Jakarta: PT Kompas Media Nusantara.

Takwin, B. (2015). Revolusi Mental Melalui Pembangunan Sosial. In H. Panggabean, A. Supratiknya, \& J.S.A.Utama (Eds.), Revolusi Mental: Makna dan Realisasi. Seri Sumbangan Pemikiran Psikologi Untuk Bangsa (Jakarta). Himpunan Psikologi Indonesia.

Tashadi, M., Gatot, S., \& Sukirman. (1982). Sistem Gotong Royong dalam Masyarakat Pedesaan Daerah Istimewa Yogyakarta. Jakarta: Departemen Pendidikan dan Kebudayaan.

Taylor, P. M., \& Aragon, L. V. (1991). Beyond the Java Sea: Art of Indonesia's Outer Islands. Abrams.

Thomas, V. B., Selvadurai, S., Er, A. C., Lyndon, N., \& Moorthy, R. (2011). Factors influencing commitment of volunteers' in neighborhood watch organization. Journal of Social Sciences, 7(4), 569-574.

Tjahjandari, L., Setyani, T. I., Pembayun, P. S., \& Kurnia, L. H. (2017). Culture As A Capital To Improve The Local Economy Case Study In Cibuntu Village, Kuningan. Proceeding The 3 International Indonesian Forum for Asian Studies: Borderless Communities \& Nations with Borders Challenges of Globalisation. Universitas Gadjah Mada \& Universitas Islam Indonesia Yogyakarta.

Triwidodo, I. (2017, September). Pasang Surut Kehidupan Berbangsa dan Bernegara Masyarakat Indonesia. Swantara. Swantara: Majalah Triwulan Lemhanas RI. No.22. Tahun VI.

Van der Kroef, J. M. (1959). Indonesia's economic future. Pacific Affairs, 32(1), 46-72.

Van der Kroef, J. M. (1960). The changing pattern of Indonesia's representative government. The Canadian Journal of Economics and Political Science, 26(2), 215-240.

Wawointana, T. (2001). Pelestarian mapalus di Minahasa dalam rangka pengembangan kebudayaan nasional. Universitas Gadjah Mada, Yogyakarta. 
Weix, G. G. (1996). Review. Contemporary Sociology, 25(5), 646-648.

Widadi, A. (2012). 17 Agustus Merdeka dari Korupsi. Swantara: Majalah Triwulan Lemhanas RI. No.2. Tahun $I$.

Wirutomo, P. (2015a). Mewujudkan revolusi mental. In J. Sinamo (Ed.), Menggulirkan revolusi mental di berbagai bidang. Jakarta: Institut Darma Mahardika.

Wirutomo, P. (2015b). Revolusi Mental Untuk Indonesia. Swantara. Majalah Triwulan Lemhanas RI. Swantara: Majalah Triwulan Lemhanas RI No.12. Tahun IV.

Yondri, L. (2017). Situs Gunung Padang: Kebudayaan, Manusia, dan Lingkungan. Bandung: Penerbit CV. Semiotika.

Yulianto, D. (2017). Lemhannas RI Selenggarakan Pemantapan Nilai-Nilai Kebangsaan di Tarakan. Swantara: Majalah Triwulan Lemhanas RI. No.20. Tahun VI, 20.

Yuniarti, K. W. (2015). Meningkatkan Kualitas Pendidikan Masyarakat Melalui Revolusi Mental Guna Memperkuat Identitas Sosial Budaya Dalam Rangka Ketahanan Nasional. Program Pendidikan Singkat Angkatan XX Lembaga Ketahanan Nasional RI. Lembaga Ketahanan Nasional Republik Indonesia.

Zakaria, H. G. (2017). 5 Pilar Revolusi Mental: Untuk Aparatur Negara. Jakarta: Penerbit PT Elex Media Komputindo.

Zulkarnain, I. (2014). "Playable", nationalism: nusantara online and the 'gamic", reconstruction of national history.'” Journal of Social Issue in Southeast Asia, 29(1), 31-62. 